\title{
The Effectiveness of Science E-Magazine of Socioscientific Issues-Based Inquiry Model to Improve Critical Thinking Skill of Junior High School Students
}

\author{
${ }^{*}$ R D Sari ${ }^{1}$, R Agustini ${ }^{1}$, W Widodo ${ }^{2}$ \\ 1Science Education Study Program, Postgraduate Program, Universitas Negeri Surabaya, Indonesia \\ 2Department of Science Education, Faculty of Mathematics and Natural Science, Universitas Negeri Surabaya, \\ Indonesia
}

\begin{tabular}{l} 
Article Info \\
\hline Article history: \\
Received July 29, 2021 \\
Revised August 30, 2021 \\
Accepted September 19, 2021 \\
Available Online December 30, 2021 \\
\hline
\end{tabular}

Keywords:

Science e-magazine Inquiry model Sociosceintific issues Critical thinking skill

\begin{abstract}
This study aimed to improve the students' critical thinking ability through learning activities using a science e-magazine of socioscientific issues-based inquiry model on additive and addictive material. This study used a one-group pretest-posttest design. This study also investigated the validity, practicality, and effectiveness of the science e-magazine of socioscientific issues-based inquiry model on the students' critical thinking abilities. Data collection techniques used validation, observation, and test. The average students' critical thinking ability was seen from the overall n-gain score of 0.34 in moderate criteria. The data analysis technique was intended to find out the improvement of critical thinking using paired sample t-test with sig result that was 0.000 , so that if $\mathrm{H}_{0}$ is rejected, it means there was an increase in the ability of critical thinking students on VIII A class at Junior High School 1 Pamekasan after the learning activities. Students' responses and implementation were analyzed using descriptive analysis. E-magazine development was accompanied by the compiling of other learning tools such as syllabus, lesson plan, student worksheet, and critical thinking tests. E-magazine was saved in pdf format, making it easier for students to read them on smartphones or laptops. The average response of students to the learning activities was $80 \%$ and to the e-magazine was $80 \%$.
\end{abstract}

\section{INTRODUCTION}

The objective of the changes in science learning is in line with the nature of science learning and the thinking ability of students in the classroom. Many schools still implement irrelevant means to stimulate students' knowledge in science. The students need many skills to explore their ability to solve some problems and make decisions (Sribunnam et al., 2014). Science learning in schools should contain scientific processes that are applied with scientific attitudes and produce scientific products. The scientific process aims to make students understand nature based on their knowledge, and scientific attitudes aim to conduct scientific investigations responsibly to trigger students to think and produce scientific products from natural and human resources. Science today has become an integrated material since the change of competency-based curriculum into curriculum 2013.

According to Mulyasa (2015), the curriculum of 2013 aims to prepare humans to have the ability to live as faithful, productive, creative, innovative, and affective individuals and citizens through strengthening attitudes, skills, and integrated knowledge. Character-based and competency-based K13 improves the Competency-Based Curriculum (KBK) and the Education 
Unit Level Curriculum (KTSP). The integration effort is expected to provide new insights to meet the 21st century. K13 is developed which oriented towards the framework of 21st Century Skills which shows that knowledge alone is not enough without being equipped with a high level of thinking ability, one of which is critical thinking ability (Partnership for 21st Century Skill, 2002).

Critical thinking is a complex process using a high level of cognitive ability to obtain information (Choy \& Cheah, 2009). Critical thinking ability includes basic clarification, decisionmaking, and concluding, providing further explanations, hypotheses and integrations, and additional abilities (Ennis, 2011). The purpose of critical thinking is to test an opinion or idea, including making considerations or thoughts based on the opinions presented. These considerations are usually supported by responsible criteria. Critical thinking ability aims to bring up new ideas or thoughts about the problems of the world. Students will be trained how to evaluate various opinions to distinguish whether opinions are rational or irrational and right or untrue. Developing students' critical thinking ability can help students make conclusions by considering the data and facts in the field. In addition, the purpose of critical thinking is to consider and evaluate information that ultimately makes it possible to make decisions.

One of the efforts to improve student's critical thinking ability is to implement meaningful learning. The activity of meaningful learning by combining a problem-oriented to the problems surrounding what is studied or called socioscientific issues (SSI). According to Sribunnam et al. (2014) that the context of socioscientific issues (SSI) is known as the issue of science and technology that become discussions and problems in the community, for example including problems that exist in nature, social and political impacts, or even problems regarding health, general living conditions, limited energy, and economic growth that are counter to nature conservation. This can be considered in the context of socially responsible science teaching encouraging students' decisions to increase their knowledge. Some research on socioscientific issues has proven if the issue or problem in society can be a learning source for students. As well as the result of this study explains that socioscientific issues have a positive impact on students.

Previous research on socioscientific issues on android use is declared effective toward junior high school students. The statement is proved by the results of 9 students' n-gain category are moderate, and one student shows high results. The results are also supported by the learning that is well implemented and obtained a percentage of $89.8 \%$. The results reveal that using socioscientific issues on an android system can help students improve student science literacy (Prastowo \& Widodo, 2019). Other research was done by Nevarez et al. (2018) conducted at Northeastern University, America, with 100 participants. The results of the study show that learning used e-magazines had an average of 7.07 while learning by using blackboard had an average of 4.99. These results show that magazine use is better than blackboard when studying. A contributing factor is a socioscientific approach to issues. According to Zeidler \& Nichol in Bilican (2018), socioscientific issues encourage the integration of disciplines and non-scientific. Socioscientific issues can also help students give an authentic and trustworthy context. Such reallife contexts are, in turn, expected to motivate to study science content by making it seem more relevant or relatable, and engaging.

This study measures the improvement of students' critical thinking ability. Jie, et al (2015) argue that students with critical thinking ability can criticize, ask, evaluate, and reflect on the information obtained. Supported by Kazempour (2013) that teaching students critical thinking is one of the main objectives of education. Science learning in this study uses an inquiry model while focusing on scientific approaches such as observing, questioning, experimenting, analyzing (associating), and communicating. The inquiry model of critical thinking results is in line with Ramadhanti and Agustini (2021) that applying the inquiry learning model at Senior High School 1 Taman on reaction rate material can influence the increase of critical thinking ability of students. These results are derived from the increase of students' n-gain scores on each critical thinking indicator. The interpretation indicator obtained a result of 0.74 with a high category. The inference 
indicator obtained a result of 0.76 with a high category. The explanation indicator obtained a result of 0.86 with a high category, and the analytical indicator obtained a high result of 0.63 with a moderate category. Based on previous research, the focus of this study is to develop the science e-magazine of socioscientific issues-based inquiry model-assisted to improve students' critical thinking ability.

\section{RESEARCH METHOD}

This research was conducted at Junior High School 1 Pamekasan. This research was conducted in class VIII A with a total of 16 samples as a form of small-scale testing during June 2021. The model used in this research was research and development. This research developed a science emagazine of socioscientific issues-based inquiry model on additive and addictive material. Research and development measures used under the ADDIE model were:

\section{Analyze}

The activity at this stage was to analyze the need for the development of a science e-magazine of socioscientific issues-based inquiry model. At this stage, researchers made observations to science teachers at Junior High School 1 Pamekasan. The problems found related to the need for a more interesting learning atmosphere, the media used, and the learning character of students.

\section{Design}

At this stage, the activity was to design instructional tool products (syllabus, lesson plan, student worksheet, critical thinking tests, and e-magazine). The design of the instructional tool referred to additive and addictive material with socioscientific issues-based inquiry models. The emagazine design used Scribus app and was saved in pdf format.

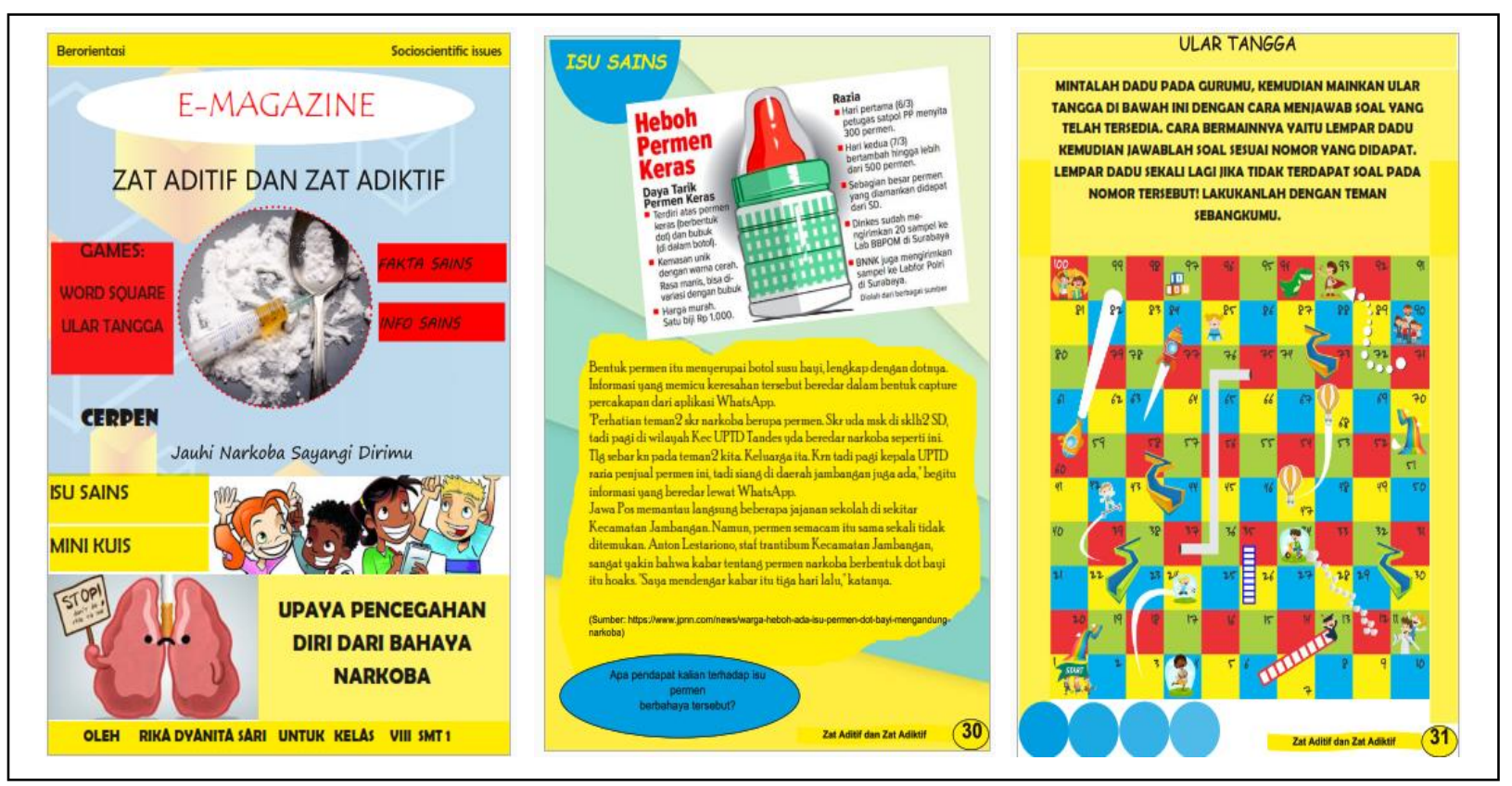

Figure 1. E-magazine product

\section{Development}

At this stage, the researchers collected the materials covering subject matter, critical thinking indicators, learning models, socioscientific issues approaches, and those were combined in the instructional tools. The development stage in this study carried out some validation of instructional tools. At this stage, the concept was then realized into an instructional tool to be used. 


\section{Implementation}

At this stage, validated learning tools were carried out. The application of the instructional tool to 16 students in VIII A class was as a form of small-scale test of research. The implementation of the instructional tool completed within each learning step based on the lesson plan.

\section{Evaluation}

The last stage was an evaluation. At this stage was to evaluate the process of e-magazine development in line with the model and approach used. Evaluation results were used to provide feedback to e-magazine users on the subsequent large-scale test.

The data collection process included validation, observation, response questionnaire, and critical thinking tests. Each assessment component on the instructional tool validation sheet was presented in four selection boxes. Before the learning was carried out, the research instrument was validated by validators based on the assessment criteria. The validation results were then analyzed descriptive-qualitatively by calculating the average score obtained from the validators. The average score was converted by using the following provision:

Table 1. Validation category criteria

\begin{tabular}{cc}
\hline Score & Category \\
\hline $10 \% \leq$ validation score $\leq 25 \%$ & Invalid \\
$25.01 \% \leq$ validation score $\leq 50 \%$ & Invalid \\
$50.01 \% \leq$ validation score $\leq 75 \%$ & Valid \\
$75.01 \leq$ validation score $\leq 100 \%$ & Very Valid \\
\hline
\end{tabular}

(Ratumanan \& Laurens, 2011)

The data collection of observation was carried out to determine the implementation of learning and obstacles during the learning by using a science E-magazine. Observations were carried out by science teachers at Junior High School 1 Pamekasan based on the activities in the lesson plan. The learning process was carried out for three meetings, and the students were given a critical thinking test after the learning was completed. The improvement of each critical thinking indicator before and after the learning process could be known by analyzing the test results and then categorized by $\mathrm{N}$-gain score according to the category in table 2.

Table 2. N-gain score category

\begin{tabular}{cc}
\hline Gain Score & Criteria \\
\hline$(<\mathrm{g}>)<0,3$ & Low \\
$0,3<(<\mathrm{g}>)<0,7$ & Medium \\
$(<\mathrm{g}>)>0,7$ & High \\
\hline
\end{tabular}

(Hake, 2002)

The research design in this try-out used a one-group pretest-posttest design. The increase in overall critical thinking could be analyzed by using the SPSS application, that was, paired sample $\mathrm{t}$-test. The hypothesis used was that if $\mathrm{H}_{0}$ was rejected, there was an increase in the critical thinking ability of VIII A class at Junior High School 1 Pamekasan after learning activities, and if H1 was rejected, then there was no improvement on the critical thinking ability of VIII A class at Junior High School 1 Pamekasan after the learning activities.

\section{RESULTS AND DISCUSSION}

\section{A. Learning Implementation}

The E-magazine that had been validated was then used in science learning with a socioscientific issues-based inquiry model. Science learning was carried out in three meetings, with a pretest given before and a posttest given after the implementation of learning. The observation result of the learning implementation is shown in Figure 2. 


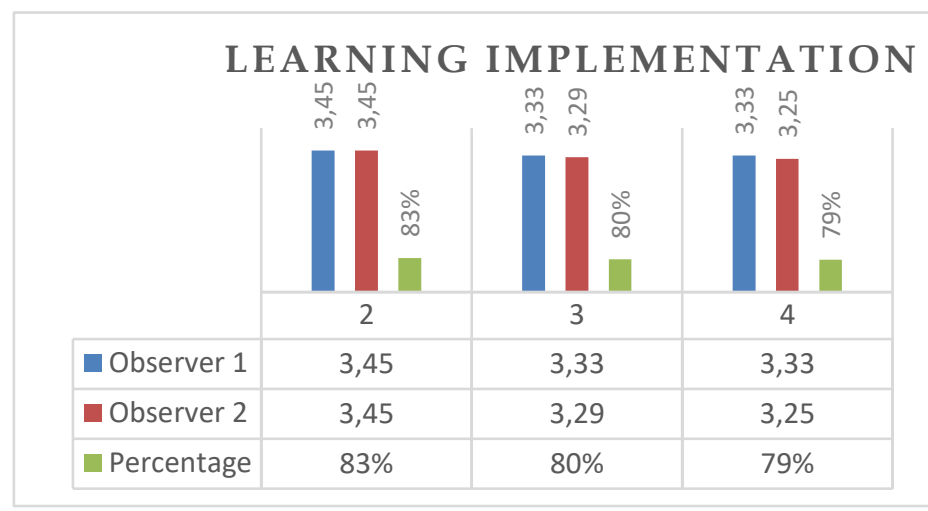

Figure 2. Learning implementation

Based on Figure 2, it can be seen that the learning implementation in VIII A class at Junior High School 1 Pamekasan by using socioscientific issues-based inquiry model using the science E-magazine was overall well done. This could be seen from the average percentage of the assessment from 2 validators that were $80 \%$. In the first meeting, the average percentage of assessment was $83 \%$, in the second meeting was $80 \%$, and in the third meeting was $79 \%$. The learning implementation also obtained a reliability value of $85.71 \%$; therefore, the data were categorized as reliable due to its reliability value was more than $75 \%$ (Borich, 1994). It can be interpreted that the teacher had started the learning very well by focusing attention and recalling the initial knowledge they have related to everyday life and thus motivating the students. This is in line with Purnamawati et al. (2017) that inquiry learning contains scientific activities that involve students to investigate, ask questions, formulate hypotheses, and test hypotheses to get correct knowledge. Scientific steps in learning inquiry allowed students to follow the procedures and scientists' thoughts to understand the concepts correctly and prevent them from misconception. Students' observation in the initial activity also showed that the activity was in line with the indicators of socioscientific issues, namely the exploration of scientific issues (Erman et al., 2019). The activity asked students to give opinions toward the issues presented by the teacher so that some students were encouraged to give their opinion.

The students' enthusiasm in following the learning activities showed that the teacher had succeeded in creating a good learning atmosphere. This is in line with Sulistyowati and Wisudawati (2014) who stated that a teacher must be able to create a learning atmosphere that is appropriate to the characteristics of the students and the material to be taught. The implementation of the socioscientific issues strategy in the first meeting was done through the discussion of dangerous content on dyes that existed around the students' environment. The students investigated several ingredients such as tomatoes, red chilies, and sauces in three different brands. In the second meeting, the issue presented was the existence of foods that contain harmful preservatives. The students then investigated several food samples such as salted fish, fresh fish, tofu, and sausage. In the third meeting, the material presented in the student worksheet was about TAR content which is harmful to the human body which led students to experiment with several types of cigarettes such as white cigarettes, filtered kretek cigarettes, and unfiltered kretek cigarettes.

This is in line with research conducted by Peeters (2016), who stated that inquiry-based science learning could facilitate the learning process. The socioscientific issues-based learning activities were in line with research conducted by Suryanti et al. (2021), in which the situation or problems involving phenomena required students to conclude the role of science and thus integrated it from various disciplines and technology as well as incorporated it directly into the life aspects. The students' action and communication were based on scientific knowledge, decision, and facts. The learning activities which employed socioscientific issues strategies made 
the students understand more about additives and addictive substances. By integrating science issues into the learning materials, the students can build and strengthen their morals and ethics (Rohmawati et al., 2018). It can be seen from the way the students conducted observation on each experimental activity and how they respond to the learning activities. In line with Sribunnam et al. (2014), socioscientific issues can be one of the considerations for science learning that is socially responsible to encourage students' decisions based on moral reasons and expansion of the scientific literacy scope. The use of learning media in VIII A class also supported the learning implementation. Through e-magazines, the students were more focused although some of them concentrated on reading and understanding the contents of E-magazines. In line with Arsyad (2017), the use of learning media could boost motivation and stimulation in learning.

There was another obstacle such as students' lack of enthusiasm for reading e-magazines. The students were not used to participate in the learning activities with inquiry models, for example, formulating hypotheses on additives and addictive substances. The students were also not used to employ socioscientific issues learning strategies as well as having difficulty in understanding the terms in science issues. The solutions were on building students' motivation to be more enthusiastic in reading e-magazines as a learning resource because it was easy to read via smartphone and laptop, explaining to the students that the learning would be carried out using an inquiry model, motivating the students by presenting issue about additive and addictive substances as well as familiarizing them to practice formulating hypotheses.

\section{B. Critical Thinking Result}

The improvement of critical thinking skills in VIII A class at Junior High School 1 Pamekasan can be seen through the total of 16 children's pre-test and post-tests. The details of their critical thinking improvement were eight students classified in both medium and low categories. These results were evidenced by the calculation of the students' N-gain toward the pre-test and posttest scores. There were no students who got $\mathrm{N}$-gain in high category due to some students still found it challenging to finish critical thinking tests on additive and addictive substances materials. The results of eight students' pre-test scores increased after being given a post-test with scores between 45 to 80 . The other eight students were classified as having critical thinking with low category because the $\mathrm{N}$-gain results were below 0.03 . The average value of $\mathrm{N}$-gain is 0.34 for medium category. Every indicator of critical thinking increased after the learning process by employing socioscientific issues-based science learning assisted by e-magazines to improve the students' critical thinking skills in junior high school. The results of critical thinking for each indicator are presented in Figure 3.

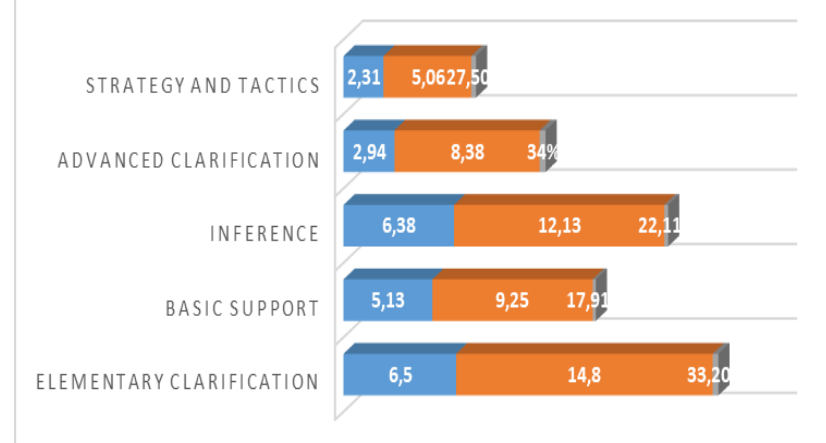

Figure 3. The improvement of critical thinking indicators

The hypothesis testing on the results of critical thinking for VIII A class was " $\mathrm{H}_{0}=$ There is no improvement on students' critical thinking skills before and after the learning activities (sig $<0.05)$ ". Whereas, " $\mathrm{H}_{1}=$ There is an improvement on students' critical thinking skills before and after learning activities (sig. $>0.05)$ ". The significance value of the paired-sample t-test was 0.000 . 
The value was smaller than 0.05 ; therefore, $\mathrm{H}_{0}$ was rejected. Thus, there was an improvement on students' critical thinking skills before and after learning activities. Before conducting the pairedsample t-test, a normality test was carried out. The results can be seen in Table 3 and Table 4 .

Table 3. Normality test

\begin{tabular}{lrrrrrrr}
\hline & \multicolumn{3}{c}{ Kolmogorov-Smirnov $^{\mathrm{a}}$} & \multicolumn{3}{c}{ Shapiro-Wilk } \\
\cline { 2 - 9 } & Statistic & Df & \multicolumn{1}{c}{ Sig. } & Statistic & df & \multicolumn{1}{c}{ Sig. } \\
\hline Pre-test score & .125 & 16 & $.200^{*}$ & .961 & 16 & .681 \\
Post-test score & .106 & 16 & $.200^{*}$ & .979 & 16 & .957 \\
\hline
\end{tabular}

Based on the results of the statistical test in table 3, the significance value of the pre-test was 0.681 and the post-test was 0.957 . These results indicated that the significance value was higher than 0.05 , so the pre-test and post-test data were normally distributed.

Table 4. Paired sample t-test

\begin{tabular}{|c|c|c|c|c|c|c|c|}
\hline \multirow[b]{3}{*}{$\begin{array}{l}\text { Critical Thinking } \\
\text { Result }\end{array}$} & \multirow[b]{3}{*}{$\begin{array}{l}\text { Pre-test Score - } \\
\text { Post-test Score }\end{array}$} & \multicolumn{3}{|c|}{ Paired Differences } & & \multirow{2}{*}{$\mathrm{df}$} & \multirow{2}{*}{$\begin{array}{l}\text { Sig. (2- } \\
\text { tailed) }\end{array}$} \\
\hline & & Mean & Std. Deviation & Std. Error Mean & & & \\
\hline & & -26.250 & 13.655 & 3.414 & -7.689 & 15 & .000 \\
\hline
\end{tabular}

The improvement on students' critical thinking skills is in line with Sadler (2004), who asserted that one of the efforts to improve students' critical thinking skills was by connecting the relevance of chemistry materials to everyday life so that the learning in the context of certain chemistry materials could be a learning source. In regard to the development of scientific literacy, socio-scientific issues are the right context to achieve the expected goals. Socioscientific issues were chosen as learning contexts because they can be used: (1) to make science learning more relevant for the students; (2) to direct learning into the expected result about nature and science (3) to increase dialogue argument; (4) to improve the ability to evaluate scientific information; and (5) to develop scientific literacy. The use of e-magazine also affected the students' understanding of the learning materials. E-magazine is a digital magazine containing additive and addictive substances material and is designed with a combination of images, fonts, and several games. In line with Nurjanah and Sukarmin (2014), the use of e-magazine in learning activities enabled students to achieve complete minimum criteria as a whole.

Inquiry learning can be used to train the students' critical thinking skills. The students' learning inquiry would be actively involved in both physical and mental learning (direct activity) through experimental activities of observing, asking questions, analyzing data, and drawing conclusion. Student-centered questions made the learning proven to improve students' critical thinking skills. Critical thinking skills can be done continuously by adjusting them to the learning characteristics (Suryanti et al., 2018). This result was supported by constructivism theory by Piaget. In constructivism theory, the process of knowledge formation occurs gradually and constantly faced with experiences or phenomena encountered by an individual (Sulistyowati \& Wisudawati, 2014). Critical thinking skills could be given through inquiry learning model which had more significant positive effects than conventional learning models. The learning model that produced good critical thinking skills was the inquiry model compared to other conventional models (Rejeki et al., 2021). The inquiry model was suitable for the renewal of learning that requires the students to record new ideas and to ask questions according to their current understanding. This is because students build understanding through guidance and challenges from the teachers (Harrison, 2014).

Socioscientific issues integrated with the inquiry learning model were appropriate for implementing the indicators of students' critical thinking. The activities covering observation of 
an issue were appropriate with elementary clarification indicator. The questioning activities with basic support indicator required the students to generate several questions. The trying-out activity with inference indicator required the students to be able to conclude the existence of food dyes from the practicum. The analysis activity toward the investigation results in the practicum was based on the advanced clarification indicators, and the communication activities were based on strategy and tactics indicator since the students could decide the problems presented by the teacher. Based on the research, it can be concluded that the socioscientific issues-based inquiry model of science e-magazine improved the students' critical thinking skills in junior high school.

\section{Student's Responses}

The students' responses presented in Figure 4 revealed that the average scores which as many as 16 students of class VIII A obtained was $80 \%$ in the good category, and the responses they had were positives to the components of the learning tools during their participation in socioscientific issues-based learning assisted by e-magazines. The first indicator of the student interest in the learning activities used was $80 \%$ in the good category. The second indicator of student interest in e-magazines was $80 \%$ in the good category.

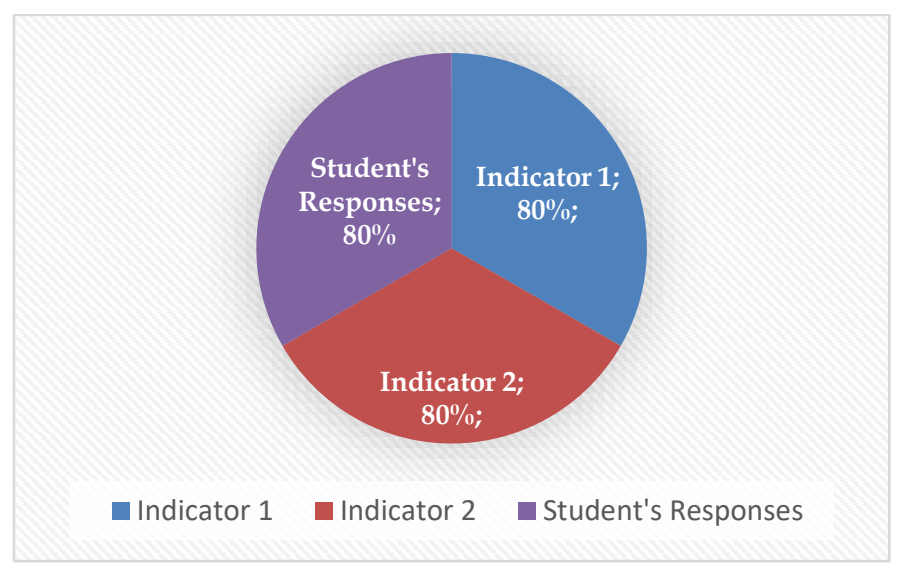

Figure 4. Student's responses

According to the results of each indicator on each student response, it revealed that the students' responses to science learning through the e-magazine science assisted by socioscientific issues-based inquiry model were good; in other words, the appropriate learning approach selected by the teacher worked out well. It was also in line with Puranto et al. (2013), who stated that one of the target abilities was developed through socioscientific issues-based learning science. It represented the level of development of a person's literacy which dealt with collecting and processing information or data from various sources or known as the thinking dimension according to the nature of science. The practical activities on additive and addictive material were done in the learning activities. The practical activities were done in meeting one were intended to identify the presence of natural and artificial dyes in food by using several food samples such as sauce, tomatoes, and red chilies. The results revealed that the natural dyes changed their color and the artificial dyes did not when soap solution was dropped into it. This kind of activity done in meeting two was to identify the presence of dangerous preservatives by using two control solutions, control (-), that contained $\mathrm{KMnO}_{4}$ liquid and aquades while the control (+) consisted of $\mathrm{KMnO}_{4}$ liquid and formalin. It was obtained that if the color was almost similar to the control solution $(+)$, the food sample contained formalin. The activity done in meeting three was to identify the TAR content in several types of cigarettes; the results showed that the darker the brown color was on the cotton, the more TAR content was in cigarettes.

The student's responses to the second indicator about the e-magazine were positive. It indicated that the use of e-magazines during the learning made them feel more enthusiastic about learning. The use of e-magazines awoke their motivation to control how they learn, helped them 
build communication, and became more active (Sithole et al., 2016). Thus, the students' responses to e-magazines and science learning by using socioscientific issues-based inquiry model assisted by e-magazines were defined as positive.

\section{CONCLUSION}

The discussion was in line with the research results which were presented; thus, it can be concluded that the socioscientific issues-based science learning tools assisted by e-magazines were claimed feasible (valid, practical, and effective) to improve students' critical thinking skills of class VIII A at Junior High School 1 Pamekasan dealing with the additives and addictive substances. Socioscientific issues-based science learning tools assisted by e-magazines improved the students' critical thinking skills and need to be further developed, especially on each indicator of critical thinking. The implication of this research was the improvement of students' critical thinking. The remedial program was implemented in developing the lesson plans of socioscientific issues-based science learning assisted by e-magazines to improve the critical thinking tests. Continuous critical thinking test practice needed to be done so that they found it easier to answer the critical thinking questions. Future research is expected to increase higher critical thinking using socioscientific issues-based learning media.

\section{REFERENCES}

Arsyad. (2017). Media Pembelajaran. Grafindo Perkasa.

Bilican, K. (2018). Analysis of pre-service science teachers' understanding of nature of science and proposed arguments on socio-scientific issues. International Journal of Research in Education and Science, 4(2). https://doi.org/10.15294/jpii.v9i2.23208

Borich, G. D. (1994). Observation skill for effective teaching. Mac Millian Publishing Company.

Choy, S. C \& Cheah, P.K (2009). Teacher perceptions of critical thinking among students and its influence on higher education. International Journal of Teaching and Learning in Higher Education, 20(2), 1812-9129.

Suryanti, Supardi, Z. A. I., \& Baginda, U. (2018). The application of inquiry learning to train critical thinking skills on light material of primary school students. Journal of Physics: Conference Series. https:// doi.org/10.1088/1742-6596/1108/1/012128

Ennis, R. H. (Ed.). (2011). The nature of critical thinking: An outline of critical thinking disposition and abilities [Conference presentation]. Sixth International Conference on Thinking, MIT, Cambridge, MA, England. https://education.illinois.edu/docs/default-source/facultydocuments/robert-ennis/thenatureofcriticalthinking_51711_000.pdf

Erman, E., Liliasari L., Ramdani, M., \& Wakhidah, N. (2019). Addressing macroscopic issues: Helping student form associations between biochemistry and sports and aiding their scientific literacy. International Journal of Science and Mathematics Education. https:// doi.org/10.1007/s10763-019-09990-3

Hake, R. R. (2002). Relationship of individual student normalized learning gains in mechanics with gender, high-school physics, and pretest scores on mathematics and spatial visualization. Physics Education Research Conference, Boise, Idaho.

Harrison, C. (2014). Assesment of inquiry skills in the sails project. Science Education Intenational, 25(1), 112-122.

Jie, S., Zhang, X. H., Zhang, X. S. (2015). How to explain the evaluation of the accuraty of patientspecific cutting blocks for total knee arthroplasty. International Orthopaedics, 35, 597-598. https://doi.org/10.1007/s00264-014-2611-8

Kazempour, E. (2013). The effect of inquiry based teaching on critical thinking of students. Journal of Social Issues \& Humanities, 1(3).

Mulyasa, E. (2015). Implementasi kurikulum 2013. PT Remaja Rosdakarya. 
Nevarez, C. L., \& McGovern, E. (2018). On the use of mobile apps in education: The impact of digital magazines on student learning. Journal of Educational Technology Systems, 47(1), 17-31. https://doi.org/10.1177/0047239518778514

Nurjanah, J. R., \& Sukarmin. (2014). Pengembangan media pembelajaran interaktif e-magazine pada materi pokok dinamika rotasi untuk SMA kelas XI. Jurnal Materi dan Pembelajaran Fisika (JMPF), 4(1).

Peeters, T. (2012). Panduan autisme terlengkap. Dian Rakyat.

Puranto, W. H., Nurohman, S., \& Wibowo, W. S. (2013). Integreted science based socio scientific

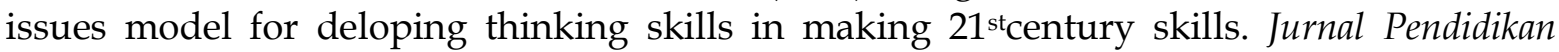
Matematika dan Sains, 1(2).

Purnamawati, D., Ertikanto, C., \& Suyatna, A. (2017). keefektifan lembar kerja siswa berbasis inkuiri untuk menumbuhkan keterampilan berpikir tingkat tinggi. Jurnal Ilmiah Pendidikan Fisika Al-Biruni. https://doi.org/10.24042/jipfalbiruni.v6i2.2070

Ramadhanti, A., \& Agustini, R. (2021). Analisis keterampilan berpikir kritis peserta didik melalui model inkuiri terbimbing pada materi laju reaksi. Jurnal Kependidikan: Jurnal Hasil Penelitian dan Kajian Kepustakaan di Bidang Pendidikan, Pengajaran dan Pembelajaran, 17(2).

Partnership for 21st Century Skill. (2002). Learning for the 21st century. https://21stcenturyskills.org

Prastowo, T., \& Widodo, W. (2019). Development of A-SSI learning media (Android Social Scientific Issues) to improve science literation in earth coating subject for first grade of junior high school. Journal of Physic: Conference Series (Miseic). https://doi.org/10.1088/17426596/1417/1/012085

Ratumanan, T. G \& Laurens, T. (2011). Penilaian hasil belajar pada tingkat satuan pendidikan. Unesa University Press.

Rohmawati, E., Widodo, W., \& Agustini, R. (2018). Membangun Kemampuan Literasi Sains Siswa Melalui Pembelajaran Berkonteks Socio-Scientific Issues Berbantuan Media Weblog. Jurnal Penelitian Pendidikan IPA. https://doi.org/10.26740/jppipa.v3n1.p8-14

Sadler, T. D. (2004). Informal reasoning regarding socioscientific issues: A critical review of research. Journal of Research in Science Teaching, 41(5). https:// doi.org/10.1002/tea.2009

Sithole, A., Kibirige, J., Mupinga D. M., \& Chiyaka E. T. (2016). Applying alternative teaching methods to import a rounded, Liberal Arts and Sciences (LAS) education: Students' reflections on the role of magazines as instructional tools. Journal of Education and Practice, $7(33)$.

Sribunnam, S., Nuangchalrem, P., \& Jansawang, N. (2014). Socio-scientific Decision Making in the Science Classroom. International Journal for Cross-Disciplinary Subjects in Education (IJCDSE), 5(4), 1777-1782.

Sulistyowati, E., \& Wisudawati, A. W. (2014). Metodologi pembelajaran IPA. Bumi Aksara.

Suryanti., Widodo, W., \& Yermiandhoko, Y. (2021). Gadget-Based Interactive Multimedia on Socio-Scientific Issues to Improve Elementary Student's Science Literacy. International Journal of Interactive Mobile Technologies (IJIM). 1865-7923.

Rejeki, S., Siswanto, \& Riyadi. (2021). Problem based learning and guided inquiry learning model on critical thinking ability. International Journal on Emerging Mathematics Education (IJEME), 5(1). https://doi.org/10.12928/ijeme.v5i1.19939 
The Effectiveness of Science E-Magazine of Socioscientific Issues-Based Inquiry Model to Improve Critical Thinking Skill of Junior High School Students

Author (s):

* Rika Dyanita Sari (Corresponding Author)

Science Education Study Program, Postgraduate Program,

Universitas Negeri Surabaya,

Jl. Lidah Wetan, Surabaya 60213, Indonesia

Email: rika.18008@mhs.unesa.ac.id

Rudiana Agustini

Science Education Study Program, Postgraduate Program,

Universitas Negeri Surabaya,

Jl. Lidah Wetan, Surabaya 60231, Indonesia

Email: rudianaagustini@unesa.ac.id

Wahono Widodo

Department of Science Education, Faculty of Mathematics and Natural Science,

Universitas Negeri Surabaya,

Jl. Ketintang, Surabaya 60231, Indonesia

Email: wahonowidodo@unesa.ac.id 